\title{
ACCLIMATIZATION FODDER BEET PLANTS UNDER TWO IRRIGATION SYSTEMS IN SALINE SOILS AT SAHL EL-TINA - NORTH SINAI
}

\author{
H. S. Khafaga ${ }^{(1)}$, H. A. M. Hiekal(2), A .S. Abdel-Nabi(1), S.F.T. Sharkawy ${ }^{(2)}$ \\ and H.M. Al-Shaer ${ }^{(3)}$ \\ (1) Plant Genetic Res. Dept., (2)Soil Cons. Dept., (3) Animal Nutrition Dept., Desert Res. \\ Center, Cairo, Egypt. \\ Corresponding author ${ }^{1}$ : dr_hussein48@hotmail.com
}

Received: Oct. 13, 2017

Accepted: Oct. 25,2017

\begin{abstract}
Soil salinity is a major problem in Egypt where salt affected lands are increasing over the productive farmland. Fodder beet plant (Beta vulgaris L. Monovert) could be a potential fodder crop for small ruminants based on its moderate nutritive value and high biomass production and its ability to grow in high salt affected soils. The aim of this study was to evaluate for fodder beet yield under traditional management practices (TMP) and improved management practices (IMP). The TMP included the practices carried out by the farmers and the other one (IMP) included the integrated practices of modified irrigation systems with applied leaching requirements, suitable planting method, application of appropriate rate of fertilization (NPK) and addition of sulfur, farmyard manure (FYM) and effective micro-organisms solution (EM). Two field experiments were conducted in farmers' fields under saline conditions of Sahl El-Tina area in 2010/2011\& 2011/2012 winter seasons. The treatments of both experiments included two irrigation systems (permanent sprinkler "PS" and surface furrows " $F l$ "), two management practices (traditional and improved), and two planting methods (one side and two sides of the ridge). The treatments were arranged in completely randomized blocks design with four replicates. The obtained results indicated that the IMP decreased soil salinity and increased water use efficiency, under modified irrigation system. Based on the results of two growing seasons, irrigation water use efficiency (IWUE) were the highest average values as 11.47 and $16.22 \mathrm{~kg} \mathrm{~m}^{-3}$ obtained with IMP\&FI and IMP\&PS treatments, respectively. Developed furrow irrigation with improved management practices resulted in higher IWUE by $23.4 \%$. While, modified sprinkler irrigation system with improved management practices led to increase in IWUE by $17.9 \%$. It is clear that application of IMP significantly increase of growth characters, fresh yield (leaves and roots) of fodder beet by 5\% as compared to the TMP. Consequently, sustainable development can be achieved by application IMP for mitigate soil salinity hazards and enhance the productivity of fodder beet as forage crops in Sahl El-Tina area, North Sinai to solve the feed shortage problem around the year.
\end{abstract}

Key words: Marginal environment, Fodder Beet, Management practices, Irrigation water use efficiency, Irrigation systems, planting method.

\section{INTRODUCTION}

Through the International Center for Biosaline Agriculture (ICBA) and the Desert Research Center (DRC) joint project cooperation, research efforts have been done to grow habits for cultivation some forage crops under high salinity conditions, along with their physiological responses and production levels. Mixing drainage water with Nile water is the main source of irrigation water in Sahl El-Tina area (av. salinity of irrigation water is $1046 \mathrm{ppm}$ ). Forage production in Egypt is one of the urgent problems that needed extensive agricultural development in reclaimed and desert areas. Soils in such areas represent an obvious limiting factor for growth and yield of some forage crops. Therefore, the 
improvement of salt tolerance of such crops deserved the highest priority (Khan, et al., 2002). Pre-sowing seed hardening considered well known treatments for improving plant growth and correct the balance of chemical constituents that has been disturbed in most plants under saline condition (Salama and Abdel-Basset, 1987; El-Agamy et al., 1991 and Sallam, (1992). However, the extensive production of such forage plants under saline water irrigation requires some data on the convenient treatments that influence on growth, biochemical metabolism and re-productivity processes under saline condition. For such purpose, many investigators are trying to use macro and micronutrients through fertilization under saline condition (El-Kadi et al., 1983, Kishk et al., 1985, EL-Sarag, 2013, and Abdelaal and Tawfik, 2015).

One of the important criteria in determining best management practices for irrigated agriculture that understands the interaction between irrigation system performance and the movement of water and solutes through the soil. Irrigation method and volume of water have a pronounced influence on salt accumulation and distribution, Ayers and Westcot (1989). Over the past decade, there has been a gradual shift in Egypt towards development of farm mechanization systems. Efficient use of equipment requires tilling basins and furrows in long strips, Clemmens et al. (1999)

Materechera (2011) stated that irrigation was increasing salinity in the soils and points to the need for adherence to sound irrigation water management practices especially appropriate irrigation scheduling. Management was carried out taking into account the improvement of irrigation systems and the evolution of soilhydrogeological process of agrarian landscapes under the influence of irrigation and drainage, Morozov et al. (2010).

Therefore, the present work aimed to evaluate the effectiveness of two planting methods (one side and two sides of the ridges) and two irrigation systems (surface long furrows and permanent sprinkler) on growth parameters, and forage yield of fodder beet plant grown under two agro management practices at Sahl El-tina, North Sinai conditions.

\section{MATERIALS AND METHODS}

Two field experiments were conducted under saline conditions at Sahl El-tina, North Sinai Governorate. The aims were to study the effect of two planting methods (one side and two sides of the ridge) and two irrigation systems (surface long furrows and permanent sprinkler) under traditional and improved management practices on growth, and forage yield of fodder beet plants (Beta vulgaris L. Monovert). Each experiment which resemble the interaction between two planting methods under two agro management practices (traditional management practices "TMP" and improved management practices "IMP"). Each experiment was arranged in a randomized complete block design in four replicates, The location of the permanent sprinkler irrigation (PS) experiment sited at a Latitude of $30^{\circ}$ $54^{\prime} 45.37^{\prime \prime} \mathrm{N}$ and longitude of $32^{\circ} 23^{\prime} 35.22^{\prime \prime}$ $E$, while the location of surface furrows irrigation (FI) experiment sited at a Latitude of $31^{\circ} 0^{\prime} 41.97^{\prime \prime} \mathrm{N}$ and longitude of $32^{\circ} 29^{\prime}$ 28.92" E.

Agricultural practices and irrigation methods were evaluated. Traditional and Improved management practices (IMP) were compared. In the Traditional management practices (TMP) each basic unit included 5 ridges, $65 \mathrm{~cm}$ apart and $20 \mathrm{~m}$ length, comprising an area of $65 \mathrm{~m}^{2}$. Seeds of fodder beet (Beta vulgaris L. Monovert) were planted at rate of $7.5 \mathrm{~kg} \mathrm{ha}^{-1}$ on $1^{\text {st. }}$ November 2010/2011\& 2011/2012 winter seasons in hills distanced at $20 \mathrm{~cm}$ apart. Concerning the developed surface irrigation system as described according to Hiekal et al. (2016), equal parts of PVC pipes as water spill pipes that has $1.0 \mathrm{~m}$ length $(63 \mathrm{~mm}$ diameter) installed in irrigation 
channel ridge along the farm upper end, which deliver the irrigated water according to the equally flow rate (one spill pipe each furrow) through temporary dam used to keep a constant hydraulic head, and realize adequately inflow rate during irrigation events. The distance between furrows was $0.70 \mathrm{~m}$, and $70 \mathrm{~m}$ length. Each basic unit included 5 ridges comprising an area of 245 $\mathrm{m}^{2}$, individual furrow inflow rates were measured in both TMP and IMP and adjusted by use of a volumetric container and stopwatch which predetermined according to the technique of Merriam and Keller (1978). In IMP, inflow rates were set at 105 L.min $^{-1}$.furrow ${ }^{-1}$. The amount of accumulated water applied was recorded by a flowmeter installed on the delivery line of each irrigation system. Soil surface slope was $0.1 \%$ in run direction. Irrigation cutoff was at $85 \%$ of plot length and runoff was negligible, which the furrows were closedends. With respect to the improved permanent sprinkler (IPS) irrigation, the amount of irrigation water was estimated by a flowmeter installed in the delivery line of the irrigation system. Lateral PVC lines were buried at $1 \mathrm{~m}$ depth $(75 / 63 \mathrm{~mm})$. The used sprinkler heads (Rain Bird 30 TNT), with a $32 \mathrm{~mm}$ diameter of PVC riser (1m height above soil surface) for each head, were arranged and fitted on the lateral line and the system operated at an average pressure of 1.75bar with an average discharge of 21.8 L-min ${ }^{-1}$ for each sprinkler. The distance between sprinklers was $14 \mathrm{~m}$ by $14 \mathrm{~m}$ between laterals. The area of each treatment was irrigated by a separate lateral line, and the irrigation event was carried out individually for each treatment.

The IMP of fodder beet plant included leveling soil surface using LASER technique for surface irrigation system with longitudinal slope $0.1 \%$, tillage at $20 \mathrm{~cm}$ with chisel plow 7 blades (two passes), addition, $50 \mathrm{~m}^{3}$-ha ${ }^{-1}$ Organic manure, $75 \mathrm{Kg} \mathrm{P}_{2} \mathrm{O}_{5}-\mathrm{ha}^{-1}$ as mono calcium phosphate (Super phosphate) and $200 \mathrm{~kg}$ Sulfur ha-1 added during soil preparation and $120 \mathrm{Kg} \mathrm{N} \mathrm{ha}$ as ammonium sulfate added in 2 equal doses at sowing date and after 60 day from sowing date. $50 \mathrm{~L}^{-1}$ Effective microorganisms solution (EM) is effective, easy to prepare and use and leaves behind enhanced bacterial population increasing soil fertility for all times to come. EM applied with organic matter changed the plant rhizosphere into more conducive conditions. Soil microbial populations were 1.5 times higher in the organic matter treated with EM than for organic matter alone, Zhao (1995).

The TMP of fodder beet plant included 20 $\mathrm{m}^{3}$ ha $^{-1}$ Organic manure, $31 \mathrm{Kg} \mathrm{P}_{2} \mathrm{O}_{5}-\mathrm{ha}^{-1}$ as mono calcium phosphate (Super phosphate) added during soil preparation and $60 \mathrm{Kg} \mathrm{N}$ ha $^{-1}$ as ammonium nitrate added after 60 day from sowing date.

\section{Measurements}

\section{- Estimation of water requirements} and irrigation schedule:

The irrigation water applied when the available soil moisture content depleted to nearly $50 \%$ in the upper $60 \mathrm{~cm}$ of soil profile in order to raise the soil moisture content to field capacity. Weather data collected to calculate the reference crop evapotranspiration (ETo) using PenmanMonteith's formula and the methodologies formulated by Allen et al. (1998) to work out the crop evapotranspiration (ETc), leaching requirements and determining the irrigation schedule. The amount of irrigation water calculated according to the equation given by James (1988):

$$
\mathrm{ET}_{\mathrm{c}}=\mathrm{I}+\mathrm{P} \pm \Delta \mathrm{S}-\mathrm{R}-\mathrm{D}
$$

Where:

$E T_{c}=$ crop evapotranspiration;

$I$ = irrigation amount;

$P=$ precipitation;

$\Delta S=$ change of soil water storage;

$R$ = surface runoff; and

$D=$ deep percolation below crop root zone.

Since the precipitation in the growing season was small, surface runoff could be ignored under the experiment conditions, 
therefore, the irrigation amount was estimated using the field balance equation as follow:

$$
I=E T_{C} \pm \Delta S-D
$$

\section{- Quantities of irrigation water:}

The total amount of irrigation water that meets the requirements of the evaporation, transpiration and then the biological processes of plants developing in addition to the amount of water needed for salt leaching and adjust the salt concentration in the root zone under conditions of water quality used in the project sites for irrigation, and assuming that the efficiency of salt leaching $100 \%$, using the following relationship:

$$
A W=\frac{E T_{c}}{1-L R}
$$

Where:

$\mathrm{AW}$ = the amount of applied irrigation water that meets the needs of plants and salt leaching (mm-season $\left.{ }^{-1}\right)$

$E T_{c}=$ water needs of the crop cultivated $\mathrm{mm} / \mathrm{season}$ (Annual Crop Water Demand)

LR = Leaching requirements expressed in the form of a decimal leaching fraction.

Calculated amounts of irrigation water and leaching requirements (LR) under either permanent sprinkler irrigation (PS), or long furrows irrigation ( $\mathrm{Fl})$ according to James (1988), field conditions (soil and water conditions) LR were added as 20 and $12 \%$ of water requirements with furrow and sprinkler irrigation, respectively.

\section{- Estimation of soil moisture content:}

Soil samples were collected using soil auger sampler from randomly places from each treatment to determine soil moisture distribution gravimetrically, starting at soil surface down to $0.75 \mathrm{~m}$ with increment of $0.15 \mathrm{~m}$ and it calculated on volumetric basis (Walker, 1989).

\section{- Application efficiency (AE\%):}

Irrigation water application efficiency (AE\%) was calculated for the $75 \mathrm{~cm}$ soil depth according to James (1988) as an average values of $2^{\text {nd. }}, 4^{\text {th. }}$ and $6^{\text {th. }}$ irrigation events of $\mathrm{Fl}$ system, while, it were average values of $2^{\text {nd. }}, 5^{\text {th. }}, 8^{\text {th. }}$ and $10^{\text {th. }}$ irrigation events of PS system. As an average value for considered irrigation events in the $1^{\text {st. }}$ and $2^{\text {nd. }}$ seasons. The water application efficiency equation was calculated as follow: $A E=\left(W_{s} / W_{t}\right)^{*} 100$, where: $\mathrm{AE}=$ water application efficiency, $\%, W_{s}=$ amount of water stored in the root zone, $\mathrm{m}^{3}$, and $\mathrm{W}_{\mathrm{f}}=$ amount of water added to each plot, $\mathrm{m}^{3}$.

\section{- Irrigation water use efficiency (IWUE):}

IWUE was measured according to James (1988) as follows:

$$
I W U E=\frac{Y}{W_{a}}
$$

Where:

IWUE= irrigation water use efficiency, $\mathrm{kg} \mathrm{m}^{-3}$,

$\mathrm{Y}=$ total yield, $\mathrm{kg} \mathrm{ha}^{-1}$, and

$\mathrm{W}_{\mathrm{a}}=$ total applied water, $\mathrm{m}^{3} \mathrm{ha}^{-1}$

\section{- Plant measurements}

Two plant samples after 90 days from sowing date was randomly taken from each plot and separated into leaves and roots to determine the following characters; plant height, root length and root diameter. At harvesting time (180 days from planting date) fresh yield.ha ${ }^{-1}$ was determined. Misra (1964).

\section{- Statistical analysis}

All data were subjected to the proper statistical analysis of variance according to the procedure outlined by Steel and Torrie (1960). Combined analysis for the two growing seasons was practiced as results followed similar trend. The mean values were compared at 0.05 level of probability by least significant differences (LSD) test. 


\section{- Soil properties:}

For determination some soil physical properties according to the methods described by Klute (1986) and some soil chemical properties according to the methods described by Black (1983). Some properties for the experimental sites before addition the IMP for fodder beet cultivation are represented in Table (1). Data illustrated that the soil texture varied from loamy sand to sandy loam. The soil bulk density (BD) for soil surface layers is ranged from 1.46 to 1.7 $\mathrm{g} \mathrm{cm}^{-3}$, indicating that it is high respectively. Cresswell and Hamilton (2002) and McKenzie et al. (2004) stated that both BD and porosity give a good indication of the suitability for root growth and soil permeability.
With respect to the moisture characteristics of the investigated soils, data in Table (1) illustrated that the average values of available water content varied from 8.79 to 10.89 ( $v$ \%) for the loamy sand and sandy loam soil, respectively. Because of the low soil organic matter for these soils. The content of soil organic matter for the investigated farms is not excesses about $0.3 \%$. $1.0 \%$ organic carbon is the accepted critical value below which fertility and stability are likely to suffer. Available phosphorus tends to be less available in these soils, because of their values of $\mathrm{pH}$ are approximately equal or higher than 8 . The available phosphorus values is ranged from 8.5 to $13.4 \mathrm{ppm}$ for the soil layers. Similarly, the exchangeable potassium values for these soils are low and varied

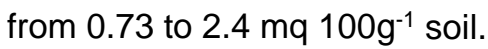

Table (1): Some properties for the experimental sites (as an average of soil depth 0$60 \mathrm{~cm}$ ) before fodder beet cultivation at Sahl El-Tina, Egypt.

\begin{tabular}{|c|c|c|c|c|}
\hline Farm Irrigation system & \multicolumn{2}{|c|}{ PS } & \multicolumn{2}{|c|}{$\mathrm{FI}$} \\
\hline soil depth $(\mathrm{cm})$ & $0-30$ & $30-60$ & $0-30$ & $30-60$ \\
\hline Soil texture class* & LS & $\mathrm{S}$ & \multicolumn{2}{|c|}{ SL } \\
\hline Bulk density $\left(\mathrm{g} \mathrm{m}^{-3}\right)$ & 1.64 & 1.7 & 1.46 & 1.5 \\
\hline Saturated hydraulic conductivity $\left(\mathrm{cm} \mathrm{h}^{-1}\right)$ & 11.28 & & \multicolumn{2}{|c|}{3.95} \\
\hline Field Capacity (v\%) & 17 & & \multicolumn{2}{|c|}{19.9} \\
\hline Wilting point $(\mathrm{V} \%)$ & 8.21 & & \multicolumn{2}{|c|}{9.01} \\
\hline Available water (v\%) & \multicolumn{2}{|c|}{8.79} & \multicolumn{2}{|c|}{10.89} \\
\hline $\mathrm{pH}$ & 8.01 & 8.1 & 8.1 & 8.04 \\
\hline$E C\left(\mathrm{dS} \mathrm{m}^{-1}\right)$ & 5.46 & 4.85 & 7.74 & 6.68 \\
\hline ESP (\%) & 16.3 & 16.3 & 41 & 26.6 \\
\hline Organic matter (\%) & 0.18 & 0.2 & 0.3 & 0.2 \\
\hline Total nitrogen (\%) & 0.1 & 0.16 & 0.1 & 0.09 \\
\hline Available phosphorus (ppm) & 8.5 & 9.4 & 11.5 & 13.4 \\
\hline Exchangeable potassium (meq $100 \mathrm{~g} \mathrm{soil}^{-1}$ ) & 0.73 & 0.95 & 1.2 & 2.4 \\
\hline Water table level $(\mathrm{cm})$ & \multicolumn{2}{|c|}{$84(80-90)$} & \multicolumn{2}{|c|}{$77(75-82)$} \\
\hline Avg. Salinity of drainage water $\left(\mathrm{dS} \mathrm{m}^{-1}\right)$ & \multicolumn{2}{|c|}{20.5} & \multicolumn{2}{|c|}{6.8} \\
\hline
\end{tabular}

* LS = Loamy sand, S= Sandy, and SL= Sandy loam 
The spatial variations within the Sahl ElTina area were very clear in respect to soil salinity for both of the soil surface and subsurface layers. The investigated soils characterized by moderate to severe salt affected, where the salinity for these farms varied from 4.85 to $7.74 \mathrm{dS} \mathrm{m}^{-1}$. However, the presence of the soluble salt in soil is sufficient to interfere with vegetation, or plant growth. From another point, $\mathrm{pH}$ values for the studied soils are moderately alkaline (7.9 to 8.04). It is worth to mention that the water table level at experiment area is low $(<1 \mathrm{~m})$ and varied during the season and between seasons. As shown in Table (1), the average water table level ranged between 75 and $90 \mathrm{~cm}$ with an approximately average of 77-84 cm, indicating that these soils have moderately shallow depth to water table level (50$100 \mathrm{~cm}$ ). FAO-AGL (2002) stated that water tables at shallow depth contribute to cause water logging and / or salinity in soils. Data illustrated that the salinity of drainage water reached to $20.5 \mathrm{dS}^{-\mathrm{m}^{-1}}$ at PS farm, this led to increase the salinity problems (secondary salinization) for the soils and grown plants, where water table raises by capillary to the soil surface.

\section{- Irrigation water properties:}

Some properties of irrigation water (El Salam Canal) indicated in Table (2)

\section{RESULTS AND DISCUSSION}

\section{- Effect of Improved Management} Practices (IMP) on Soil Properties:

Through two years of reclamation and utilization of improved management practices, soil properties were enhanced Fig. (1) showed that the IMP\&LF treatment, there was very pronounced decrease in EC values, but there values were still higher than the critical limit of $4 \mathrm{dS} \mathrm{m}^{-1}$, because of the EC value for the farm in initial was the higher $\left(7.74\right.$, and $6.68 \mathrm{dS} \mathrm{m}^{-1}$ for the surface and subsurface soil layers, respectively). In general, the decrement percentages in the soil EC values were varied from 11 to $46 \%$ for the subsurface and surface soil layers by IMP\&FI treatment, respectively. While, the decrement percentages in the soil EC values from 14 to $23 \%$ in the subsurface and surface soil layers by IMP\&PS treatment, respectively. Used of IMP along two years led to change the moderately and severe saline soils to slightly and moderate saline soils.

\section{- Irrigation water applied:}

The total amount of irrigation water that meets the requirements of the evaporation, transpiration and then the biological processes of plants developing in addition to the amount of water needed for salt leaching and adjust the salt concentration in the root zone under conditions of water quality used for irrigation, and assuming that the efficiency of salt leaching as $100 \%$, through the treatments are shown in Fig.(2). The differences in applied irrigation water between PS and FI treatments may be attributed to superior PS treatment of good distribution uniformity and less evaporation lost from the upper soil layer compared with FI treatment. On the other side, long furrows of IMP\&FI saved irrigation water in first and second seasons by 17 and 19\% in average, respectively, as compared with short furrows of TMP\&FI, Also, PS\&IMP treatment saved irrigation water in first and second seasons by 15 and $14 \%$ in average, respectively, as compared with TMP\&PS treatment (Noreldin et al., 2016).

Table (2): Some chemical properties of the irrigation water.

\begin{tabular}{|c|c|c|c|c|c|c|c|c|c|c|c|}
\hline \multirow[t]{2}{*}{ Season } & \multirow{2}{*}{$\begin{array}{c}\text { Irrig. } \\
\text { System }\end{array}$} & \multirow[t]{2}{*}{$\mathrm{pH}$} & \multirow{2}{*}{$\begin{array}{c}\text { EC } \\
\left(\mathrm{dS} \cdot \mathrm{m}^{-1}\right)\end{array}$} & \multicolumn{4}{|c|}{ Soluble Cations $\left(\mathrm{mg} \mathrm{L}^{-1}\right)$} & \multicolumn{3}{|c|}{ Soluble Anions $\left(\mathrm{mg} \mathrm{L}^{-1}\right)$} & \multirow[t]{2}{*}{ SAR } \\
\hline & & & & $\mathrm{Ca}^{++}$ & $\mathrm{Mg}^{++}$ & $\mathrm{Na}^{+}$ & $\mathrm{K}^{+}$ & $\mathrm{HCO}_{3}^{-}$ & $\mathrm{Cl}^{-}$ & $\mathrm{SO}_{4}^{--}$ & \\
\hline \multirow{2}{*}{$1^{\text {st }}$} & PS & 7.25 & 2.09 & 7.36 & 1.63 & 10.23 & 1.68 & 7.64 & 9.72 & 3.54 & 4.83 \\
\hline & FI & 7.36 & 3.35 & 10.91 & 7.55 & 12.55 & 2.5 & 2.59 & 22.67 & 8.24 & 4.13 \\
\hline \multirow{2}{*}{$2^{\text {nd }}$} & PS & 7.13 & 2.54 & 5.03 & 7.02 & 12.85 & 0.52 & 4.43 & 14.23 & 6.76 & 5.24 \\
\hline & FI & 7.08 & 3.26 & 6.06 & 8.12 & 18.05 & 0.4 & 6.47 & 17.14 & 9.02 & 6.78 \\
\hline
\end{tabular}




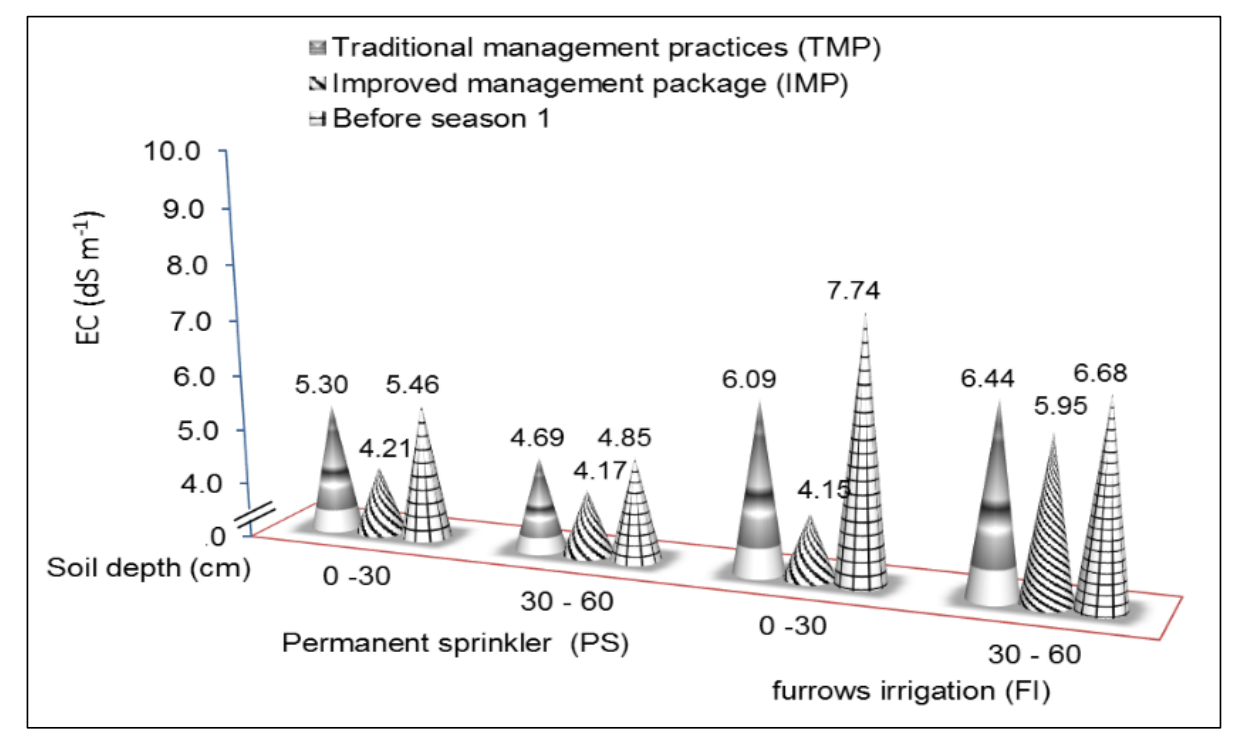

Fig. (1): Soil salinity affected by utilization of different management practices after two cultivated seasons.

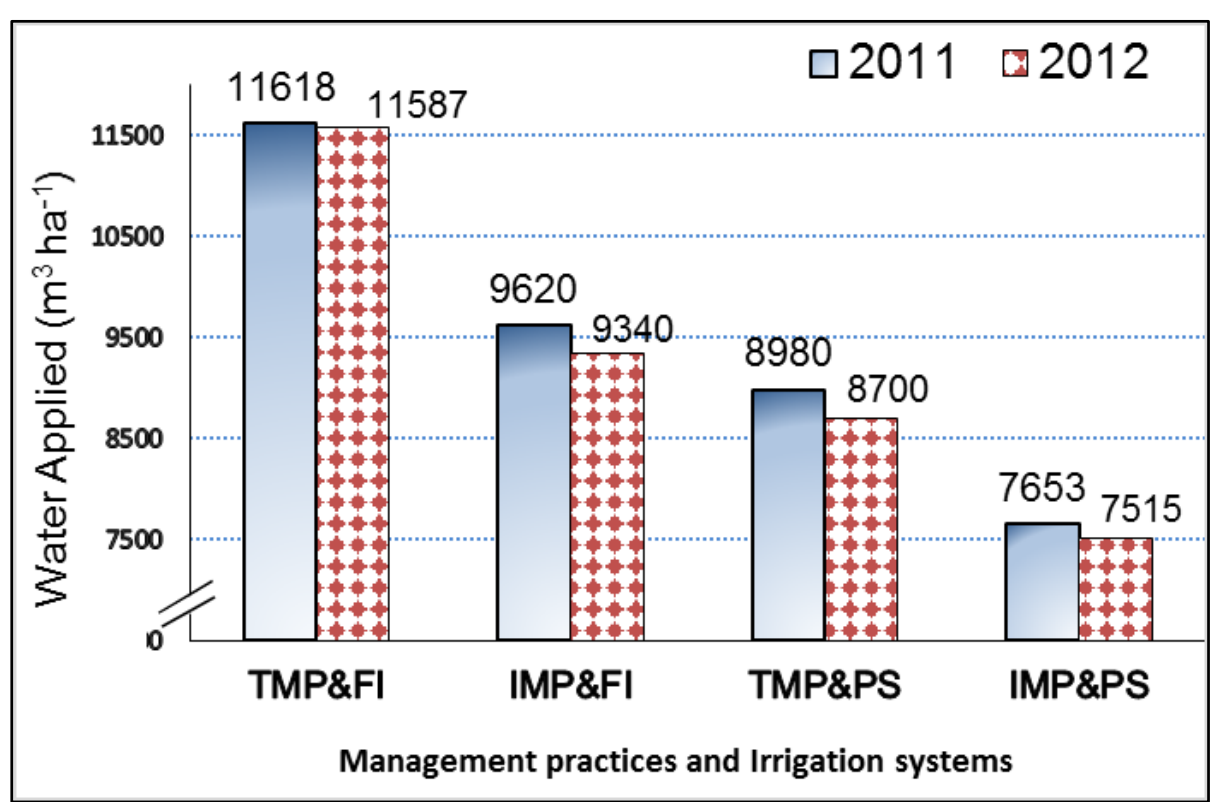

Fig. (2): The total average amounts of applied irrigation water by irrigation systems and management practices.

- Growth and yield characters:

1- Effect of agro management systems

Generally, all studied traits for fodder beet plants (Table 3 ) significantly increased with applied IMP treatments as compared with the traditional planting (control). The increments percent that obtained from applied IMP were reached 9.8, 12.0, 44.1,
15.9 and $10.4 \%$ for plant height, root length, root diameter, total fresh forage yields for leaves and roots, respectively as compared with TMP. Magdy et al. (2013) reported that increased forage production from fodder beet could enhance ruminant livestock production substantially without requiring additional inputs from resource-poor livestock farmers. 


\section{2- Effect of Irrigation systems}

Regarding the effect of irrigation system (Table 4) it was obvious clearly that permanent sprinkler (PS) was better than furrow irrigation $(\mathrm{FI})$ for inducing a significantly increase in all growth yield and its characters of fodder beet plant. The increments percent that obtained from applied PS irrigation were reached 17.7, $19.6,10.0,18.1$ and $13.2 \%$ for plant height, root length, root diameter, total fresh forage yields for leaves and roots, respectively as compared with FI treatment.

\section{3- Effect of method of planting}

Concerning, the effect of methods of planting treatments on growth yield and its components in (Table 5) showed that planting seeds of fodder beet on one side was better than on two sides for plant height, root length, root diameter which recorded $58.33 \mathrm{~cm}, 34.80 \mathrm{~cm}$ and $14.45 \mathrm{~cm}$ respectively as compared with $49.42 \mathrm{~cm}$, $23.00 \mathrm{~cm}$ and $12.66 \mathrm{~cm}$, respectively on two sides. On contrast planting seeds of fodder beet on two sides achieved the highest significant mean values for fresh forage yield for leaves and roots of fodder beet the increments reached 14.5 and $13.6 \%$ as compared with planting on one side, respectively.

Table (3): Effect of improved and traditional agro management systems on yield and its components of fodder beet (Combined analysis of two seasons).

\begin{tabular}{|c|c|c|c|c|c|}
\hline \multirow[t]{2}{*}{ Management practices } & \multirow[t]{2}{*}{$\begin{array}{l}\text { Plant } \\
\text { height } \\
(\mathrm{cm})\end{array}$} & \multirow[t]{2}{*}{$\begin{array}{l}\text { Root } \\
\text { length } \\
(\mathrm{cm})\end{array}$} & \multirow[t]{2}{*}{$\begin{array}{c}\text { Root } \\
\text { diameter } \\
(\mathrm{cm})\end{array}$} & \multicolumn{2}{|c|}{$\begin{array}{l}\text { Total fresh yields for } \\
\text { leaves and roots } \\
\left.\text { (Ton ha } \text { h }^{-1}\right)\end{array}$} \\
\hline & & & & Leaves & Roots \\
\hline Improved (IMP) & 56.39 & 30.54 & 16.01 & 26.52 & 76.63 \\
\hline Traditional (TMP) & 51.36 & 27.26 & 11.11 & 22.89 & 69.44 \\
\hline L.S.D. at 0.05 & 1.21 & 0.77 & 0.21 & 0.68 & 1.97 \\
\hline
\end{tabular}

Table (4): Effect of Farm Irrigation system on growth yield and its components of fodder beet (Combined analysis of two seasons).

\begin{tabular}{|c|c|c|c|c|c|}
\hline \multirow[t]{2}{*}{ Irrigation system } & \multirow{2}{*}{$\begin{array}{l}\text { Plant } \\
\text { height } \\
(\mathrm{cm})\end{array}$} & \multirow{2}{*}{$\begin{array}{l}\text { Root } \\
\text { length } \\
\text { (cm) }\end{array}$} & \multirow{2}{*}{$\begin{array}{c}\text { Root } \\
\text { diameter } \\
\text { (cm) }\end{array}$} & \multicolumn{2}{|c|}{$\begin{array}{c}\text { Total fresh yields for leaves and } \\
\text { roots }\left(\text { Ton ha }{ }^{-1}\right)\end{array}$} \\
\hline & & & & Leaves & Roots \\
\hline Permanent Sprinkler (PS) & 58.28 & 31.48 & 14.20 & 26.75 & 77.55 \\
\hline Furrow Surface (FI) & 49.52 & 26.33 & 12.91 & 22.66 & 68.54 \\
\hline L.S.D. at 0.05 & 0.76 & 0.41 & 0.30 & 1.13 & 1.17 \\
\hline
\end{tabular}

Table (5): Effect of methods of planting on growth yield and its components of fodder beet (Combined analysis of two seasons).

\begin{tabular}{|c|c|c|c|c|c|}
\hline \multirow[t]{2}{*}{$\begin{array}{l}\text { Methods of } \\
\text { planting }\end{array}$} & \multirow{2}{*}{$\begin{array}{c}\text { Plant } \\
\text { height } \\
(\mathrm{cm})\end{array}$} & \multirow{2}{*}{$\begin{array}{l}\text { Root } \\
\text { length } \\
(\mathrm{cm})\end{array}$} & \multirow{2}{*}{$\begin{array}{c}\text { Root } \\
\text { diameter } \\
\text { (cm) }\end{array}$} & \multicolumn{2}{|c|}{$\begin{array}{c}\text { Total fresh yields for leaves and } \\
\text { roots }\left(\text { Ton ha }{ }^{-1}\right)\end{array}$} \\
\hline & & & & Leaves & Roots \\
\hline On one side & 58.33 & 34.80 & 14.45 & 23.04 & 68.38 \\
\hline On two side & 49.42 & 23.00 & 12.66 & 26.37 & 77.71 \\
\hline L.S.D. at 0.05 & 1.83 & 0.97 & 0.92 & 1.43 & 2.12 \\
\hline
\end{tabular}




\section{4- Effect of interaction}

The interaction between irrigation systems, methods of planting and different agro management practices had significant effects on fodder beet growth, yield and its components are represented in Table (6). Generally, PS treatment combined with planting on one side under IMP achieved the highest mean values for plant height, root length and root diameter as compared with the other interaction treatments. Whereas total fresh forage yield for leaves and roots surpassed with planting fodder beet under PS treatment combined with planting on two sides under IMP method as compared with the other interaction treatments.

The recorded results indicated that there was a decrease in different growth measurements of fodder beet grown under saline conditions especially with traditional planting. These data are agreed to that findings by several authors including; Missak (1972); David and Nobel (1979); Wassif et al. (1983); Kishk et al. (1985); Datta and Dayal (1988) and El-Gaaly (1989) on different plant species. The retarding effect of salinity on growth of fodder beet might be
David ascribed to the following factors: A). Inability of roots to absorb sufficient amount of water due to the high osmotic pressure of the external saline solution (Meiri et al., 1971 and Heikal, 1976). B). High rate of energy consumption in building up the osmoregulatants such as proline, glycine betain. etc, that would be accumulated in plant cells in concentrations enough to regulate the osmotic pressure between vacuoles and cytoplasm (Bernstein, 1975; Greenway and Munns, 1980 and Munns et al., 1982).

On the other hand, several investigators have proved the significant role of some applied micronutrients for correcting the adverse effect of salinity for improving salt tolerance of some field crops (Farrag, 1978; El-Kadi et al., 1979; El-Bagouri et al., 1983; Wassif et al., 1983; Shukla and Nukhi, 1985 and Dahdoh, 1986). Moreover, the efficiency of the application of some trace elements with IMP such as $\mathrm{ZnSO}_{4} . \mathrm{MnSO}_{4}$ and $\mathrm{KCl}$ may be with a corrective and/or compensative effect on mineral balance (Misra, 1964).

Table (6): Effect of interaction between irrigation methods, methods of planting and agro management systems on growth yield and its components of fodder beet at harvesting stage. (Combined analysis of two seasons)

\begin{tabular}{|c|c|c|c|c|c|c|c|}
\hline \multirow{2}{*}{$\begin{array}{c}\text { Manage- } \\
\text { ment } \\
\text { practices }\end{array}$} & \multirow[t]{2}{*}{$\begin{array}{l}\text { Irrigation } \\
\text { systems }\end{array}$} & \multirow[t]{2}{*}{$\begin{array}{l}\text { Methods of } \\
\text { planting }\end{array}$} & \multirow{2}{*}{$\begin{array}{c}\text { Plant } \\
\text { height } \\
(\mathrm{cm})\end{array}$} & \multirow{2}{*}{$\begin{array}{c}\text { Root } \\
\text { length } \\
(\mathrm{cm})\end{array}$} & \multirow[t]{2}{*}{$\begin{array}{l}\text { Root dia. } \\
\text { (cm) }\end{array}$} & \multicolumn{2}{|c|}{$\begin{array}{l}\text { Total fresh yield } \\
(\text { Ton ha-1) }\end{array}$} \\
\hline & & & & & & leaves & Roots \\
\hline \multirow[t]{4}{*}{ IMP } & \multirow[t]{2}{*}{ PS } & one side & 65.81 & 39.6 & 18.40 & 27.90 & 75.23 \\
\hline & & two sides & 60.00 & 27.9 & 15.00 & 30.34 & 90.43 \\
\hline & \multirow[t]{2}{*}{$\mathrm{FI}$} & one side & 57.32 & 34.07 & 16.00 & 22.71 & 64.32 \\
\hline & & two sides & 42.43 & 20.6 & 14.62 & 25.11 & 76.54 \\
\hline \multirow[t]{4}{*}{ TMP } & \multirow[t]{2}{*}{ PS } & one side & 57.5 & 35.5 & 12.40 & 22.43 & 70.32 \\
\hline & & two sides & 49.8 & 22.9 & 11.00 & 26.31 & 74.21 \\
\hline & \multirow[t]{2}{*}{$\mathrm{Fl}$} & one side & 52.7 & 30.03 & 11.00 & 19.11 & 63.65 \\
\hline & & two sides & 45.44 & 20.6 & 10.02 & 23.71 & 69.65 \\
\hline & \multicolumn{2}{|c|}{ L.S.D. at 0.05} & 1.04 & 0.87 & 0.32 & 0.86 & 2.44 \\
\hline
\end{tabular}


Concerning, planting methods, Bassal et al. (1998), reported that planting on ridges was better than on rows for yield and its components of canola crop, in addition they achieved the following advantages 1) Uniform planting, which ensures an appropriate plant population, thus helping to secure the highest yield. 2) More controlled irrigation, hoeing, fertilization and better pest control management. 3) The plants are less susceptible to lodging, as stalks become situated in the center of the furrows after the last hoeing. The plants are firmly fixed by roots and can better utilize water and nutrients, resulting in good yields. Similar results were obtained by Clarke et al. (1978), and Morrison et al. (1988).

Regarding added the suitable doses of fertilizer with improving management, several investigators have proved the significant role of some applied treatments for correcting the adverse effect on salinity for improving salt tolerance of some field crops (Farrag 1978; El-Kadi et al., 1979; Dahdoh, 1986, Khogali et al., 2011, Chakwizira et al., 2013 and Chakwizira et al., 2014)
However, under high light intensity that prevailing at North Sinai this treatment inhibits photorespiration especially in $\mathrm{C} 3$ crop plants. Therefore, the net assimilates increased that led to growth parameters increments such as plant height, leave length and root diameter as well as economic forage yields (Nonomura and Benson, 1992a\&b , Cheng and Kung, 1994 and Li et al., 1995). This finding may be due to the role of Microorganism for reduced harmful or negative effect of salinity on growth (El-Desouky and Atawia 1998) and (El-Shamey and Ibrahim 2004).

\section{- Performance of irrigation systems:}

Effects of irrigation systems and agro management practices on average amounts of water applied, amount of lost water by deep percolation (D) and $A E \%$ :

The performance parameters of the irrigation systems were evaluated and the data are signed in Fig. (3).

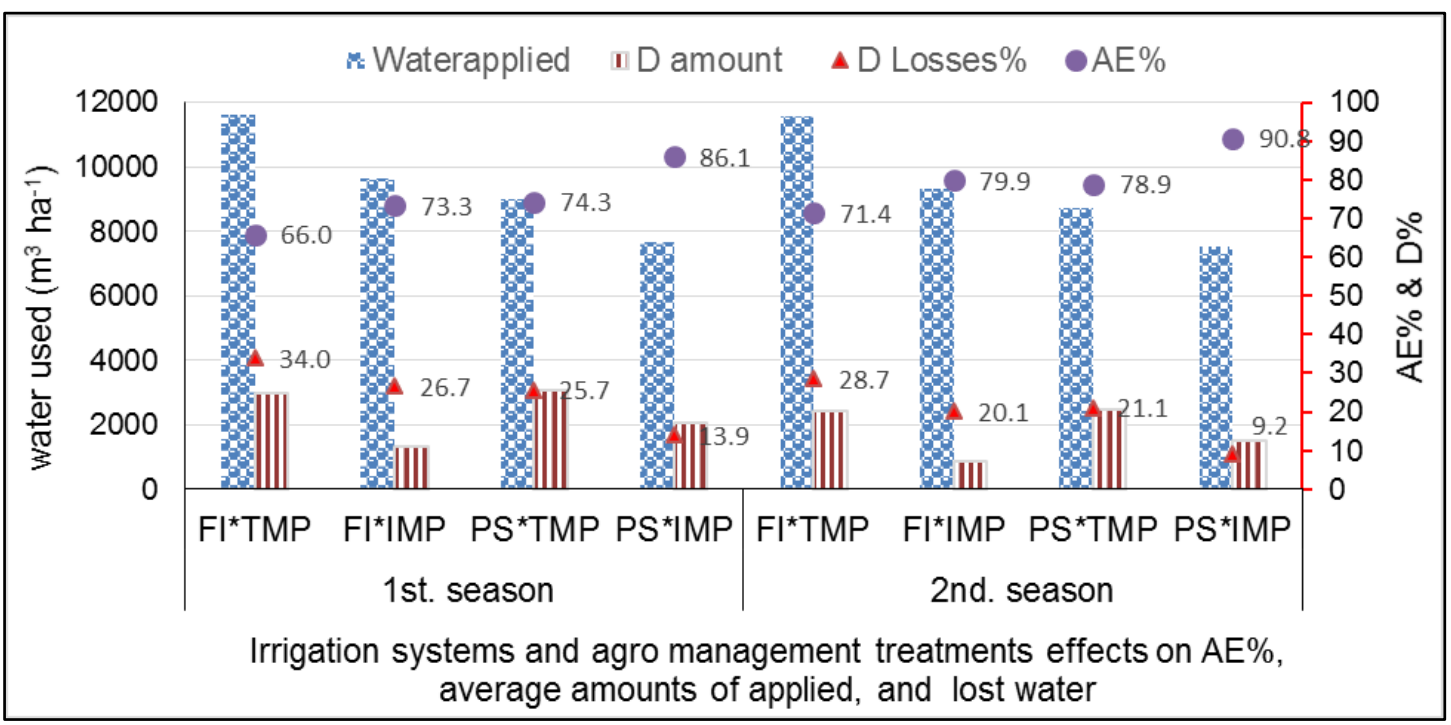

Fig. (3): Performance of irrigation systems and agro management practices on water used, water lost by deep percolation (D) and water application efficiency (AE\%). 
The parameter of water application efficiency, AE\%, showed that under IMP\&PS in first season was $86.1 \%$ recorded as the highest value and TMP\&PS came in second order which recorded $74.3 \%$. while, in second season the highest value recorded as $90.8 \%$ and IMP\&FI came in second order which recorded $80 \%$.

The values of deep percolation losses (D\%) with first season showed that about 13.9 and $26.7 \%$ of the water applied lost by PS and FI systems, respectively, were not available for the crop. While, in TMP the losses of water were 25.7 and $34 \%$ of irrigation water by $\mathrm{PS}$ and $\mathrm{FI}$, respectively. These losses reduced in the second season which recorded 9.2 and $20.1 \%$ under IMP\&PS and IMP\&FI, respectively, also the same trend under TMP were 21.1 and $28.7 \%$ of irrigation water lost under root zone by deep percolation through TMP\&PS and TMP\&FI, respectively.

\section{- Irrigation water use efficiency (IWUE):}

The average values of IWUE shown in Fig. (4). The highest average value $15.87 \mathrm{~kg}$ $\mathrm{m}^{-3}$ recorded by IMP\&PS treatment, the increment reached $18.7 \%$ compared to TMP\&PS treatment, with non-significant difference existed between the planting methods treatments. Meanwhile, treatment IMP\&FI resulted average value of $11.2 \mathrm{~kg} \mathrm{~m}$
${ }^{3}$, the increment reached to $20.8 \%$ compared to TMP\&FI treatment with non-significant difference existed between the planting methods treatments. The second season obtained the same trend with IMP\&PS and IMP\&FI where recorded the higher values 16.22 and $11.74 \mathrm{~kg} \mathrm{~m}^{-3}$, respectively of IWUE compared the TMP treatments, the increments reached to 17.9 and $23.4 \%$, respectively.

Generally, the average recorded values of IWUE with PS were higher than those obtained by Furrow surface at any level of agro management practices.

These results were in accordance with that obtained by Hiekal (2007), with better water distribution in the soil profile; consequently, less water lost by deep percolation along furrow length, especially for early season irrigations, where the high infiltration rates can result in low application efficiencies with the TMP\&FI compared with IMP\&FI. Moreover, the IWUE in the soils that treated by improved soil and water management was the higher as compared to that traditional method, the difference in yield is sufficient to interest the farmers to do the extra work involved in changing the traditional irrigation practices to rationalize their cultivated areas in order to save water and time of irrigation.

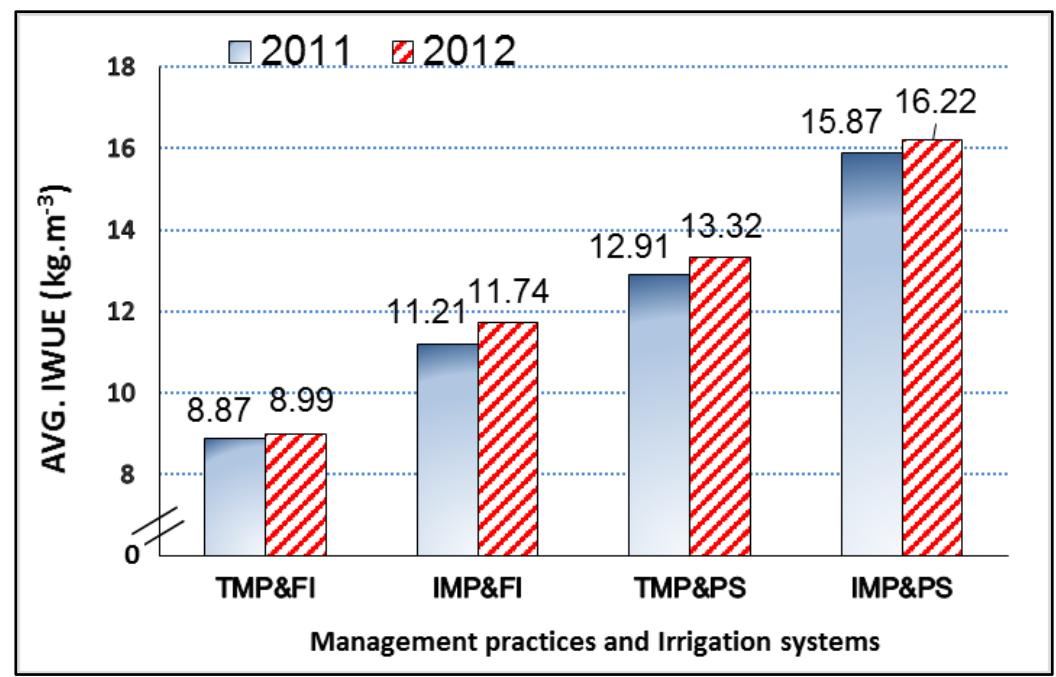

Fig. (4): Average values of irrigation water use efficiency (IWUE) for fodder beet fresh yield cultivated by different management practices for two growing seasons. 
According to Maas (1990), Carmier et al. (2006) and Hussein and Alva (2014) reported that adequate availability of water and nutrients is important to support optimal plant growth and production in the arid and semi-arid regions. Proper available nitrogen enhanced the growth of plants and lowered the adverse effect on growth caused by water stress, Salvador et al. (2013).

\section{SUMMARY AND CONCLUSION}

Used of improved management practices IMP with long furrows saved irrigation water in first and second seasons by 17 and 19\% in average, respectively, compared with (TMP), while, the decrement percentage in the EC values was varied from 11 to $46 \%$ for the subsurface soil layer of IMP\&FI treatment. By IMP along two years led to change the moderately and severe saline soils to slightly and moderate saline soils, respectively, where its impact was very pronounced in the soil surface layer.

It was obvious clearly that permanent sprinkler (PS) was better than furrow surface irrigation $(\mathrm{Fl})$ for inducing a significantly increase in all growth and yield characters of fodder beet plants. Also, planting fodder beet under PS recorded the highest significant mean values for plant height, root length, root diameter, total fresh forage yields for leaves and roots. Obtained data clearly showed that the cultivation of fodder beet crop on row spacing with to sides had the bigger impact on the yield.

The highest total fresh forage yield for leaves and roots was achieved by planting fodder beet under PS treatment combined with planting on two sides under IMP interaction which recorded 30.34 and 90.43 ton ha-1 ${ }^{-1}$ respectively, as compared with different interaction treatment. Meanwhile, application of IMP with planting fodder beet under PS on one side interaction treatment recorded the second order. Based on the results of two growing seasons, the highest average IWUE were 11.47 and $16.22 \mathrm{~kg} \mathrm{~m}^{-3}$ obtained with IMP\&FI and IMP\&PS treatments, respectively, under the conditions of the experiment farms.

\section{ACKNOWLEDGMENT}

This work was supported in part by ICBA. It also has been done under the help of the DRC team of the project: "Adaptation to Climate Change in WANA Marginal Environments through Sustainable Crop and Livestock Diversification". A Joint Project between Desert Research Center of Egypt (DRC) and the International Center Biosaline Agriculture (ICBA), Dubai, UAE.

\section{REFERENCES}

Abdelaal, Kh. A.A. and S. F. Tawfik (2015). Response of sugar beet plant (Beta vulgaris L.) to mineral nitrogen fertilization and bio-fertilizers. Int. J. Curr. Microbiol. App. Sci. 4(9): 677-688.

Allen, R. G., L. S. Pereira, D. Raes; and M. Smith (1998). Crop evapotranspiration. Guidelines for computing crop water requirements. FAO Irrigation and Drainage. Paper No. 56, FAO, Rome, Italy.

Ayers, R. S. and D. W. Westcot (1989). Water quality for irrigation. FAO Irrigation Drainage Paper 29, FAO, Rome, Italy.

Bassal, S. A.A., M.M. Lesjta and A.A. Leilah (1998). Effect of planting method, plant population density and plant distribution on Canola (Brassica Napus, L.) Productivity, Proc. 8th Conf. Agron., Suez Canal U., Ismailia, Egypt, .28-29 Nov. P. 578- 585

Bernstein, L. (1975). Effects of salinity and sodicity on plant growth. A. Rev. Phytopathal, 13: 295-312.

Black, C. A. (1983). Methods of soil analysis. Part 2, Agron. Monogr. No.9, ASA, Madison, WI, USA.

Carmier, A., Y. Aharoni, M. Edelstein, N. Umiel, A. Hagiladi, E. Yousef, M. Nikbachat, A. Zenou and J. Miron (2006). Effects of irrigation and plant density on yield, composition and in vitro digestibility of a new forage sorghum variety, TAL, at 
two-maturity stage. Animal Feed Science and Technology, 131: 121 - 133.

Chakwizira, E., J. M. de Ruiter and S. Maley (2014). Growth, nitrogen partitioning and nutritive value of fodder beet crops grown under different application rates of nitrogen fertilzer. New Zealand Journal of Agricultural Research 57: 75-89

Chakwizira, E., R. Gillespie, S. Maley, M. George and A. Michel (2013). Water and nitrogen use efficiency of forage kale crops. Agronomy New Zealand 43: 1-16.

Cheng, W.H. and H.H. Kung (1994). Methanol production and use. PP. 253260. Marcel Dekker Inc., New York and Hong Kong.

Clarke, J.M., F. R. Clarke and G.M. Simson (1978). Effect of method and rate of seeding on yield of Brassica napus. Canadian J. of Plant Sci., 58 (2): 549550.

Clemmens, A. J., Z. El-Haddad and T. S. Strelkoff (1999). Assessing the potential for modern surface irrigation in Egypt. Trans. of the ASAE 42 (4): 995-1008.

Cresswell, H. P. and Hamilton (2002). Bulk Density and Pore Space Relations. "In: Soil Physical Measurement and Interpretation for Land Evaluation, Eds. McKenzie, N. J.; H. P. Cresswell and K. J. Coughlan", CSIRO Publishing: Collingwood, Victoria. P: 35 - 58.

Dahdoh, M.S.A. (1986). Response of different crops to zinc application. Ph. D. Thesis Fac. of Agric., Ain Shams U.

Datta, K.S. and J. Dayal (1988). Effect of salinity on germination and early seedling growth of guar (Cyamopsis tetragonoloba L.). Indian J. Plant Physiol., 31, 357-363.

David, J. L. and P. S. Nobel (1979). Salinity effects on leaf anatomy. Consequences for photosynthesis. Plant Physiology, 63: 700-703.

El-Agamy, A.L., N.N. El-Hefnawy, E.T. Kishk and E.A. Khalifa (1991). Response of wheat to some seed hardening treatments under saline conditions. Minufiya, J. Agric. Res., 16 (2) .
El-Bagouri, I.H., M.M. Wassif, M.A. El-Kadi and S.A. Sabet (1983). Response of barley to foliar application of some micronutrients under the conditions of saline water irrigation and highly calcareous soil. Desert Inst. Bull., A.R.E. 14: 1-15.

El-Desouky, S.A. and A.A.R. Atawia (1998). Growth performance of some citrus rootstocks under saline conditions. Alex. J. Agric. Res. 43 (3): 231 - 254.

El-Gaaly, F.M.M. (1989). Study of some physiological indices for salt tolerance of some plants. Ph. D. Thesis, Fac. of Sci., Al-Azhar U., Girls Branch.

El-Kadi, M.A., I.H. El-Bagouri, M.M. Wassif and S.A. Sabet (1979). The effect of soil and foliar application of zinc and interaction with $\mathrm{N}$ and $\mathrm{P}$ on yield and chemical composition of some crops under the conditions of highly calcareous soils. II. Field studies of sesame and wheat. Desert Inst. Bull., A.R.E., 29: 277285.

El-Kadi, M.A., M.M. Wassif, A.A. Robieshy and M.G. Afifi (1983). Response of sunflower plants to micronutrients fertilizer using saline water irrigation under highly calcareous soil conditions. Desert Inst. Bull., A.R.E.; No. 14: 110119.

EL-Sarag, Eman (2013). Response of fodder beet cultivars to water stress and nitrogen fertilization in semi-arid regions. American-Eurasian J. Agric. \& Environ. Sci., 13 (9): 1168-1175.

El-Shamey, I. Z. and I. S. Ibrahim (2004): The effect of paclobutrazol (PP333), Proline and salicylic acid (SA) on growth parameters, yield and some biochemical contents of wheat plant under salt stress. 9th Conf. Agric. Dev. Res., Fac. Agric., Ain Shams U., Cairo, Egypt, Annals Agric. Sci., Sp. Issue, 1: 161-185.

FAO-AGL (2002). Global Network on Integrated Soil Management for Sustainable Use of Salt-Affected Soils. FAO-AGL, Land and Plant Nutrition 
Management

Service

(http://www.fao.org/ag/AGL/agll/spush).

Farrag, A.A. (1978). Salt tolerance studies on broad been using some micronutrients. Ph. D. Thesis, Fac. of Agric., Cairo U.

Greenway, H. and R. Munns (1980). Mechanism of salt tolerance in nonhalophytes. Ann. Rev. Plant Physiol., 31: 149-90.

Heikal, M.M.D. (1976). Changes in the water content and mineral composition of some plant over a range of salinity stresses. Assiut U. Bull. Sci., 5: 17-29.

Hiekal, H. A. M. (2007). Efficiency of surge furrow irrigation system on soil water distribution uniformity under calcareous soils irrigated by saline water. Arab Conf. of Soil and Water Mgt. for Sust. Agric. Devlop., 10-11 Apr., 2007, Fac. of Agric., Mansoura U., 97-107, Egypt.

Hiekal, H. A. M., H. S. Khafaga, S. F. T. Sharkawy, A. A. Ali1 and A. Al-Dakheel (2016). Enhancing irrigation system and improving soil and crop management for forage sorghum production in marginal environment. Egypt. J. Appl. Sci., 31(11): $259-292$

Hussein, M. M. and A. K. Alva (2014). Growth, yield and water use efficiency of forage sorghum as affected by NPK fertilizer and deficit irrigation. American Journal of Plant Sciences, 5: 2134 2140.

James, L. G. (1988). Principles of farm irrigation system design. Jone Willey \& Sons (Ed.), N Y, pp. 543.

Khan, M. A., A. Zaib and R. Jelte (2002). Fodder beet "A new fodder crop for salt affected lands of Pakistan". In Tasks for vegetation science 37: "Prospects for saline agriculture", Edited by R. Ahmad and K. A. Malik, pp 215-229.

Khogali, M.E., Y.M.I. Dagash and M.G. ElHag (2011). Productivity of fodder beet (Beta vulgaris var.Crassa) cultivars affected by nitrogen and plant spacing. Agric. and Biology J. of N. America 2(5): 791-798.
Kishk, E.T., A.A. Robishy and O.M. Ali (1985). Utilization of some micronutrients as a regulator for growth of sudan-grass plants, grown under saline and calcareous soil conditions. Desert Inst. Bull., A.R.E., Vol. 35 (1): 219-231.

Klute, A. "Ed."(1986). Water Retention: Laboratory Methods. Chapter 26: Hbook of Methods of Soil Analysis. Part 1. Second Ed. Am. Soc. Agron. Soil Sci. Soc. Am., Madison, WI., USA.

Li, Y., G. Gupta, J. M. Jochi and A. K. Siyumbana (1995). Effect of methanol on soybean photosythesis and chlorohyll. J. Plant Nutrition, 18(9): 1875-1880.

Maas, E. V. (1990). Crop Salt Tolerance. "In: Agricultural Salinity Assessment and Management, Ed. Tanji, K. K.". ASCE Manuals and Reports on Engineering Practice No. 71, ASCE, Reston, Va., 262 $-304$.

Magdy, M. M., M. A. El-Nahrawy, M. A. Abdu and S. A. Shams (2013). Development of fodder resources in Sinai: The role of forage crops in agriculture development, North SinaiGovernorate, Egypt. J. agron., 12 (1): 2937.

McKenzie, N. J., D. J. Jacquier, R. F. Isbell and K. L. Brown (2004). Australian Soils and Landscapes an Illustrated Compendium. CSIRO Publishing: Collingwood, Victoria, Hardback, 416 pp.

Materechera, S. A. (2011). Soil salinity in irrigated fields used for urban agriculture under a semi-arid environment of South Africa. African Journal of Agricultural Research, 6(16): 3747 - 3754.

Meiri, A., J. Kamburoff and A. PoljakoffMayber (1971). Response of bean plants to sodium chloride and sodium sulphate salinization. Ann. Bot., 35: 837-847.

Merriam, J. L. and J. Keller (1978). Farm irrigation system evaluation: A guide for management. Hbook "Farm irrigation system evaluation: a guide for management". 1978 pp. 271 pp.

Misra, D.K. (1964). Arid zone research work. Indian Fmg, 14: 18-19. 
Missak, N.L. (1972). Seasonal effect on growth, anatomy and metabolism of some Rincinus communis $L$. varieties subjected to different sodium chloride concentrations. M. Sc. Thesis, Fac. Sci., Cairo U.

Morozov, V., V. Ushkarenko and P. Laze (2010). Integrate Water Resources Management on the Irrigated Lands of the South of Ukraine in the Global Climate Changes Conditions. BALWOIS 2010 - Ohrid, Republic of Macedonia 25, 29 May, Pp: 3.

Morrison, I.N.R. Khan and A. Rashid (1988). Effect of seeding methods and soil crusting on establishment of rapeseed (Brassica napus.) and mustard (B. Juncea). Field Crop Research. 19(1): 2739.

Munns, R., H. Greenway, R. Delane and J. Gibbs (1982). Ion concentration and carbohydrate status of the elongating leaf tissue of Hordium vulgare growing at high external $\mathrm{NaCl}$. II. Cause of the growth reduction. J. Exp. Bot., 33: 574-583.

Nonomura, A. M. and A. A. Benson (1992 a). The path of carbon in photosynthesis: improved crop yields with methanol. Proc. Nat. Acad. Sci., USA, 89: 97949798.

Nonomura, A. M. and A. A. Benson (1992 b). The path of carbon in photosynthesis: Methanol and light. In: Research in photosynthesis proc. Of the IXth inter. Photosynthesis congress. Vol. 3, part 18, PP. 911-914. Kluwer Academic, dordrecht.

Noreldin, T., H.O. Sakr, S. Abdou and H. Awad (2016). Simulation of water management for fodder beet to reduce yield losses under late season drought. Cogent Food and Agriculture, Vol. 2: 1145031, 10pp.
Salama, F.M. and R. Abdel-Basset (1987). Amino acids and protein metabolism as affected by the interaction of salinity on phytohormones in wheat and kidney bean plants. Assuit J. of Agric. Sci., 12 (3): 201-213.

Sallam, H.A. (1992). Zinc seed-hardening of some wheat cultivars in relation to growth behavior and some biochemical constituents under saline conditions. Annals of Agric. Sci. Moshtohor Vol. 30 (3): 1249-1258.

Salvador, V. P., J. L. Peñuelas and D. F. Jacobs (2013). Nitrogen nutrition and drought hardening exert opposite effects on the stress tolerance of pinuspinea $L$. seedlings. Oxford J. Life Sciences Tree Physiology, 33: 221 - 232.

Shukla, U.C. and A.K. Nukhi (1985). Ameliorative role of zinc on maize growth (Zea mays L.). under salt affected soil conditions. Plant and Soil 87: 423-432.

Steel, R.G.D. and J.H. Torrie (1960). "Principle and procedures of statistics" MC-Grew-Hill Book Comp. Inc. New York.

Walker, W.R. (1989). Guidelines for designing and evaluating surface irrigation systems. FAO Irrig. and Drain. Paper 45: 148 pp., Italy.

Wassif, M.M., L.H. El-Bagouri, S.A. Sabet and A.A. Robishy (1983). Effect of irrigation with saline water at different growth stages on yields and mineral composition of some cereal crops under conditions of highly calcareous soil. Desert Inst. Bull., A.R.E., 14: 41-56.

Zhao, Q. (1995). Effect of EM on peanut production and soil fertility in the red soil region of China. Proc. $4^{\text {th }}$ Intl. Conf. on Kyusei Nature Farming. June 19 - 21, 1995, Paris, France, pp: 99 - 102.

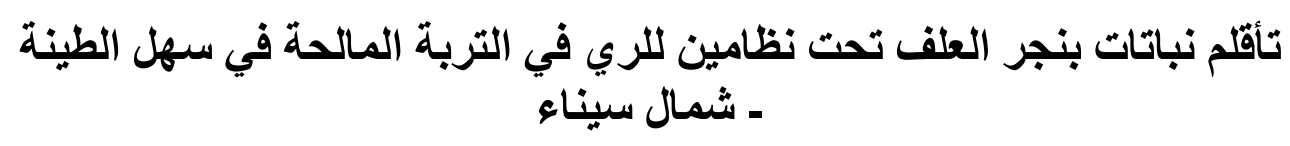




\section{H. S. Khafaga, et al.,}

\section{حسين سعيد خفاجه(1) ، حسام الاين محمد هيكل(2) ، احمد سعيد عبد النبى (1) ،}

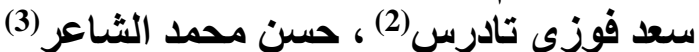

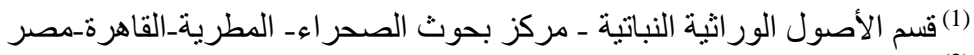

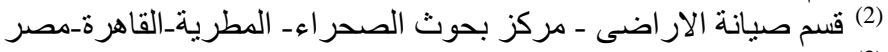

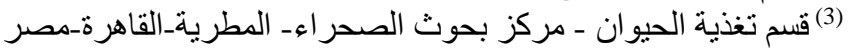

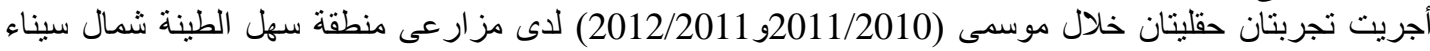

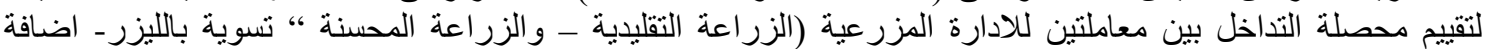

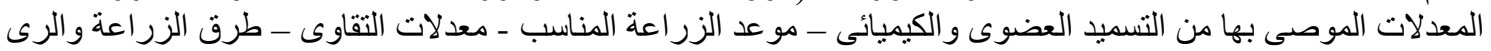

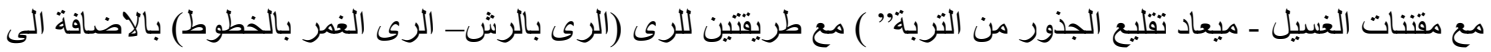

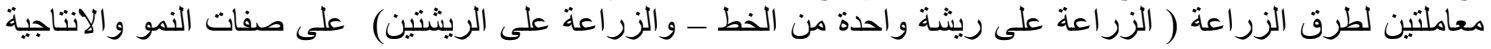

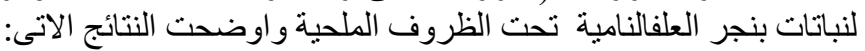

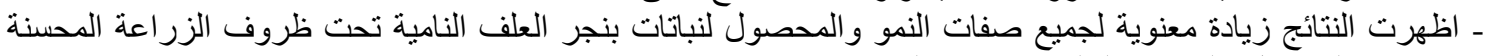

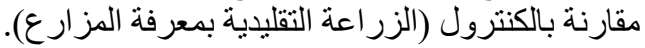

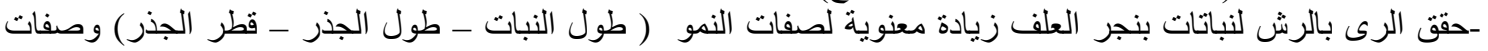

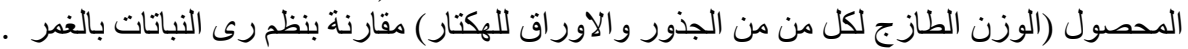

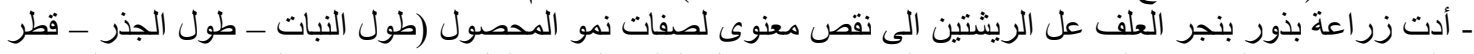

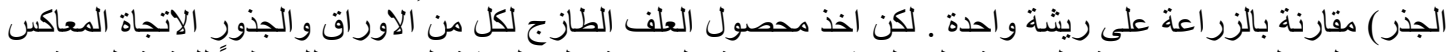

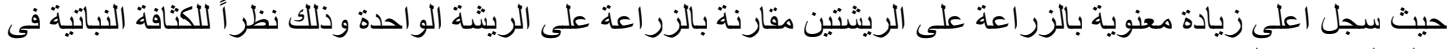
حالة الزر اعة على ريشتين. ـ بالنسبة لتاثير التفاعل بين طرق النئن الرى وطرق الزر اعة تحت نظامن من معاملات الادارة المزرعية اظهرت فروق معنوية

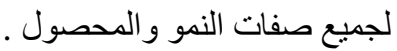

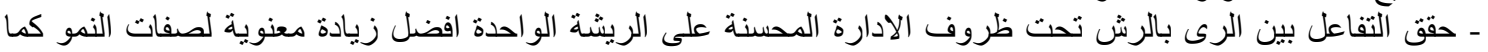

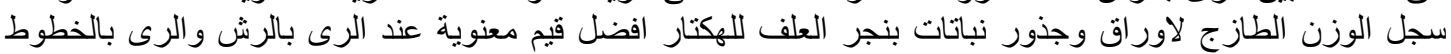
الطويلة على الريشتين تحت ظروف الزاف وجذر ناعة المحسنة. 